アジアサッカーにおける代表成績とクラブ成績との関係に関する研究 ${ }^{\dagger}$
杉 原 海 太*
平田竹 男**
政 本 晶 生 ${ }^{* *}$
久保谷 友 哉**

\title{
Study on the Relationship between Performance of the National Team and That of Clubs in Asian Football ${ }^{\dagger}$
}

\author{
Kaita SUGIHARA* ${ }^{*}$ Takeo HIRATA** ${ }^{*}$, Akio MASAMOTO** \\ and Tomoya KUBOTANI**
}

\begin{abstract}
The purpose of this paper is to discuss, in regard to Asian football teams, the question of whether improvement of club top team performance is a useful way to influence that of the senior national team's performance, by analyzing the linkage between the performance of the national team and that of club teams.

This paper examines the linkage between team performances for the 32 member associations of the AFC, which participated in the AFC Champions League, AFC Cup, and the AFC President's Cup between 2010 and 2013, by using correlation analysis and single regression analysis.

Results show that a correlation between performance of the national team and that of club teams is proved among the member associations participating in the AFC Cup and the AFC President's Cup, while it is not proved among the member associations participating the AFC Champions League. It indicates that strengthening club football is a useful way to strengthen the national team; specifically among the member associations participating in the AFC Cup and AFC President's Cup.
\end{abstract}

Key words : Asian Football, National Team, Club, Performance

\section{1. 緒言}

2014年FIFAワールドカップ本大会はドイッ の優勝で幕を閉じたが, 日本を含めたアジアの 代表チームは全てグループステージを突破でき ず，日本と韓国がグループステージ突破を果 たした2010年大会に比べると残念な結果に終 わった。それを受けてアジアサッカー連盟（以
下, AFC) のShaikh Salman bin Ebrahim Al Khalifa会長は「我々（アジアの国々）はレベ

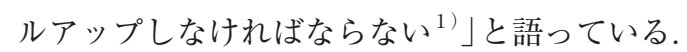

では，代表チームのレベルアップにはどのよ うな施策が必要となるのであろうか？ 近年日 本のクラブはAFCチャンピオンズリーグ（以 下，ACL）において苦戦しているが，日本サッ カー協会の原専務理事は「代表を強くするには,

\footnotetext{
${ }^{\dagger}$ 原稿受付 2014年10月22日 原稿受諾 2015年 1 月29日

*FIFA コンサルタント テ120-0025 東京都足立区千住東 2-20-12-1109

**早稲田大学大学院スポーツ科学研究科 †169-0051 東京都新宿区西早稲田 $1-6-1$

*FIFA Consultant, 2-20-12-1109, Senjuazuma, Adachi-ku, Tokyo, Japan (120-0025)

** Graduate School of Sport Sciences, Waseda University, 1-6-1, Nishi-Waseda, Shinjuku-ku, Tokyo, Japan (169-0051)
} 
国内リーグのレベルを上げていかないといけな い. ACLでなかなか結果が出せないのに, 代 表だけは勝ってくださいというのも難しい話だ し ${ }^{2)} 」$ とメントしている.このコメントから は, 原専務理事が年齢制限の無い日本代表チー ムの成績（以下，代表成績）とクラブにおける トップチームの成績（以下，クラブ成績）に関 連があると考えている事が伺える。なお上記に おいては, 日本サッカー協会の「JFA・Jリー

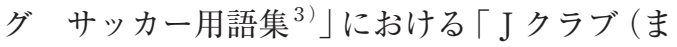
たはクラブ)」に記載されている「Jリーグの 各クラブ. Jリーグに所属する, サッカーを専 門とする運営会社.「チーム」は，Jクラブが 有するトップ, サテライト, ユース, ジュニア 等のそれぞれのチームを指すもので, クラブと は異なる」との解釈に従い, 運営会社としての クラブと大会に参加する主体としてのチームを 区別して用いており，以下においても同様とす る. 実際に隣国の韓国は, 代表チームは1986年 以降 8 大会連続でFIFAワールドカップ本大会 に出場し，クラブもACLがスタートした2002 年以降，2006年·2009年·2010年·2012年に優勝, 2004年・2011年に準優勝, と安定して好成績を 収めている。 その一方で, 例えば2006年から 3 大会連続で本大会出場を果たしているオースト ラリアは, 2014年にウェスタン・シドニー・ワ ンダラーズが決勝進出を果たした以外は, 日本 と同様にACLで目立った成績を収めていない. AFCはアジアにおけるサッカー強豪協会のク ラブだけが参加するACLに加えて，アジアに おけるサッカー中堅協会のクラブだけが参加す るAFCカップ（以下， AFCC）及びアジアに おけるサッカー弱小協会のクラブだけが参加 するAFCプレジデンッカップ（以下，AFCP. 2014年大会をもって終了）も開催しているが, AFCCにおいても代表成績とクラブ成績に関連 が見受けられるケースと見受けられないケース の両方が見られる.クウェートのクラブは2009 年, 2012年・2014年に優勝, 2010年・2011年に 準優勝とAFCCで近年圧倒的な強さを見せてい るが, クウェート代表チームは2010年ワールド
カップアジア予選・2014年ワールドカップアジ ア予選の両方で最終予選に勝ち進めなかった. またその一方で, バーレーンのクラブは2006年 に準優勝, 2008年に優勝と好成績を収め, バー レーン代表チームも2010年ワールドカップアジ ア予選において大陸間プレーオフまで勝ち進 み, ワールドカップ本大会出場まであと 1 歩と 迫った。

この様に代表成績とクラブ成績に関連が見受 けられるケースと見受けられないケースの両方 が見られる中, 代表成績とクラブ成績の関連を 統計学的に明らかにする事は, クラブのトップ チームが好成績を収める為の施策（以下，クラ ブ強化）が，年齢制限の無い代表チームが好成 績を収める為の施策（以下，代表強化）の 1 つ と成り得るか, という点における示唆が期待で きる。

代表成績に影響を及ぼす要因に関する過去 の研究を見ると，世界76の国・地域に関して, FIFAランキングにおけるポイントと 1 人当た り GDP，年間平均気温，世界人口に占める当 該国・地域の人口割合, ラテン系の国家・地域 か否か, といった主に社会的・文化的要因との 関連を分析したHoffmannら ${ }^{4)}$ や，世界178の国・ 地域に関して, FIFAランキング及びFIFAラン キングにおけるポイントと複数の社会的・政治 的要因（国民 1 人あたりGDP，人口，Freedom house reportにおける自由度指数, 共産主義及 び旧共産主義国家であるか否か, OECDメン バーであるか否か, 産油国か否か, 旧植民地国 であるか否か，等）及び複数のサッカー的要 因（大陸連盟主催のクラブチャンピオンシッ プにおいて準々決勝に進出している当該国ク ラブ数，等）との関連を分析したLeedsら ${ }^{5)}$, 2006年FIFAワールドカップ本大会に出場した 32の国・地域に関して，サッカー選手の国際移 籍と代表チームの成績の関連を分析し，国際移 籍が活発な国・地域の代表チームが好成績を残 している事を明らかにしたBaurら ${ }^{6)}$ が存在す るが, これらの先行研究において分析対象の多 くは社会的・文化的・政治的要因と代表成績と 
の関連である。これらの要因は, 関連を示す事 ができたとしても, 協会の施策により解決する 事は難しい要因である. その中で, 協会の施策 により解決が可能と考えられる, 代表成績とク ラブ成績の関連がLeedsら ${ }^{4)}$ の研究において触 れられているが, Leedsら ${ }^{5)}$ はACLを含めた大 陸連盟主催のクラブチャンピオンシップにおい て準々決勝に進出している当該国クラブ数との 関連を分析し，アジアにおいて関連は見られな いと結論付けている.

しかし, Leedsら ${ }^{5)}$ の研究はAFCCやAFCP を分析対象外としACLのみを分析対象として おり，その為上記の結論はアジアにおける全般 的な傾向を示しているとは言えない可能性があ る. また分析データも2006年大会の成績のみを 対象としており，上記の結論は2006年におけ る傾向としか言えない可能性もある. 加えて, 「準々決勝に進出している東アジアのチームは 準々決勝に進出している西アジアのチームより 強く, 準決勝に至るまで東アジアのクラブと西 アジアのクラブが対戦しないフォーマットであ るACLにおいては, 準々決勝進出する意義が, 大陸連盟主催のクラブチャンピオンシップに比 ベ小さい可能性がある」と考察しているが, そ の根拠となる事実は示されておらず，実際に 東アジアのクラブ対西アジアのクラブの対戦と なった2006年ACL決勝は 3 対 2 と接戦になっ ており, 主観的な考察である可能性がある.

そこで, 本研究では, AFC加盟協会におけ るサッカー代表チームの成績と当該協会におけ るクラブのACL, AFCC, AFCPでの成績との 関係について統計的に明らかにし，アジアにお いてクラブ強化が代表強化に繋がる有効な施策 の 1 つと成り得るか考察を行う事を目的とす る.

\section{2. 研 究手 法}

\section{1 分析対象}

本研究では, 代表チームの試合が 4 年周期で スケジュールされている事を考慮し，ACLに 参加する $\mathrm{AFC}$ 加盟協会のサッカー代表チーム
の成績（以下，代表成績）として，2010年から 2013年の 4 年間の成績を対象とした.

また当該協会におけるクラブのACL, AFCC, AFCPでの成績（以下，クラブ成績） に関しても同様に，2010年から2013年の 4 年間 の成績を対象とした.

分析対象となる加盟協会は, 2010年から2013 年の間に開催されたACL，AFCC，AFCPの何 れかに参加した延べクラブ数が 4 以上である 32 加盟協会とした。なおウズベキスタンはAFCC も ACLも参加しているが, 延べクラブ数がよ り多いACL参加加盟協会として扱った.

\section{2 分析データ}

代表成績については, FIFA公式サイト内の FIFA/Coca-Cola World Ranking ${ }^{7)} に$ お拈いて 2013年12月19日付に発表されたランキングを基 に，ACL参加加盟協会におけるランキング（以 下, ACL内FIFA Ranking), AFCC参加加盟協 会におけるランキング（以下，AFCC内FIFA Ranking), AFCP参加加盟協会におけるラン キング（以下，AFCP内FIFA Ranking）を用 いる.なおFIFA/Coca-Cola World Rankingは, 過去 4 年間の代表チームの試合結果に基づき算 出されたポイントを基に決定されている.

クラブ成績に関しては，ヨーロッパ大陸連盟 （以下，UEFA）が用いているUEFAチャンピ オンズリーグにおける協会係数の算出方法 ${ }^{8)}$ 基に, ACL Point, AFCC Point, AFCP Point の算出方法を定義し, 算出されたポイントを 基に ACL Ranking, AFCC Ranking, AFCP Rankingを求め, クラブ成績とする。 具体的に は，まずACL, AFCC, AFCPにおいて勝利し たクラブは 2 ポイント獲得し, 引き分けたク ラブは 1 ポイント獲得し, 負けたクラブは獲 得ポイント無しとする. 次に, 協会毎に, 当 該クラブの 2010 年から2013年のACL, AFCC, AFCPにおける成績に基づき獲得ポイントを 集計し，それを延べ参加クラブ数で除した值 をそれぞれACL Point, AFCC Point, AFCP Pointとする (小数点以下は四捨五入). 最後に, 
ACL Point, AFCC Point, AFCP Pointに基づ き, ACL Ranking, AFCC Ranking, AFCP Rankingを算出する.

Leedsら ${ }^{5)}$ はACLを含めた大陸連盟主催のク ラブチャンピオンシップにおいて準々決勝に進 出している当該国クラブ数との関連を分析して いるが，2010年から2013年のACLにおいては 協会毎の参加クラブ数が異なる為, 本研究にお いては不適当であるとした。

なお当該期間のACL，AFCC，AFCPにおけ る試合結果に関しては，AFC公式サイトには データが存在しない為, SOCCERWAY（http： //int.soccerway.com/( ${ }^{9)}$ を参照した.

\section{3 分析手法}

各協会の代表成績とクラブ成績との関係を検 証するために，相関分析及び単回帰分析を行っ た。

相関分析に関しては, 浦和レッドダイヤモ ンズにおける順位, 観客数, 営業収入等の相 関を分析した平田ら ${ }^{10)}$ でも用いられているス ピアマンの順位相関係数を用い, ACL内FIFA Ranking と ACL Ranking, AFCC 内FIFA RankingとAFCC Ranking, 及びAFCP内FIFA RankingとAFCP Rankingに関して分析を行っ た.

また, 単回帰分析に関しては, ACL内FIFA Ranking（従属変数）とACL Ranking（独立 変数), AFCC内FIFA Ranking (従属変数) とAFCC Ranking（独立変数）, 及びAFCP内 FIFA Ranking (従属変数) とAFCP Ranking (独 立変数）に関して分析を行った.

なお，相関分析及び回帰分析を行うにあたっ ては, IBM SPSS Statistics 19を用いた。

\section{3. 研 究 結 果}

表 1 に当該加盟協会におけるACL内FIFA Ranking及びACL Ranking, 表 2 に当該加盟協 会におけるAFCC内FIFA Ranking及びAFCC Ranking, 表 3 に当該加盟協会における 内FIFA Ranking及びAFCP Rankingを示した.
これらのデータが相関分析及び単回帰分析の入 カデータとなっている.

相関分析及び単回帰分析により算出されたス ピアマンの順位相関係数及び決定係数を表 4 に 示す.

ACL内FIFA RankingとACL Rankingに関し ては, スピアマンの順位相関係数は 0.333 となり 有意ではなく, AFCC内FIFA RankingとAFCC Rankingに関してはスピアマンの順位相関係数

表 1 当該加盟協会におけるACL内FIFA Ranking 及びACL Ranking

\begin{tabular}{|l|c|c|}
\hline \multicolumn{1}{|c|}{ 加盟協会 } & $\begin{array}{c}\text { ACL内 } \\
\text { FIFA Ranking }\end{array}$ & $\begin{array}{c}\text { ACL } \\
\text { Ranking }\end{array}$ \\
\hline Korea Republic & 3 & 1 \\
\hline Saudi Arabia & 7 & 2 \\
\hline Iran & 1 & 3 \\
\hline Japan & 2 & 4 \\
\hline Qatar & 9 & 5 \\
\hline Uzbekistan & 5 & 6 \\
\hline China PR & 8 & 7 \\
\hline Australia & 4 & 8 \\
\hline United Arab Emirates & 6 & 9 \\
\hline
\end{tabular}

表 2 当該加盟協会におけるAFCC内FIFA Ranking及びAFCC Ranking

\begin{tabular}{|l|c|c|}
\hline \multicolumn{1}{|c|}{ 加盟協会 } & $\begin{array}{c}\text { AFCC内 } \\
\text { FIFA Ranking }\end{array}$ & $\begin{array}{c}\text { AFCC } \\
\text { Ranking }\end{array}$ \\
\hline Thailand & 10 & 1 \\
\hline Kuwait & 3 & 2 \\
\hline Iraq & 4 & 3 \\
\hline Jordan & 1 & 4 \\
\hline Syria & 6 & 5 \\
\hline Vietnam & 9 & 6 \\
\hline Malaysia & 12 & 7 \\
\hline Indonesia & 14 & 8 \\
\hline Hong Kong & 8 & 9 \\
\hline Lebanon & 5 & 10 \\
\hline Myanmar & 7 & 11 \\
\hline Oman & 2 & 12 \\
\hline Singapore & 11 & 13 \\
\hline Maldives & 15 & 14 \\
\hline India & 13 & 15 \\
\hline Yemen & 16 & 16 \\
\hline
\end{tabular}


表 3 当該加盟協会におけるAFCP内FIFA Ranking 及びAFCP Ranking

\begin{tabular}{|l|c|c|}
\hline \multicolumn{1}{|c|}{ 加盟協会 } & $\begin{array}{c}\text { AFCP内 } \\
\text { FIFA Ranking }\end{array}$ & $\begin{array}{c}\text { AFCP } \\
\text { Ranking }\end{array}$ \\
\hline Kyrgyzstan & 2 & 1 \\
\hline Chinese Taipei & 3 & 2 \\
\hline Turkmenistan & 1 & 3 \\
\hline Cambodia & 6 & 4 \\
\hline Pakistan & 5 & 5 \\
\hline Nepal & 4 & 6 \\
\hline Bhutan & 7 & 7 \\
\hline
\end{tabular}

は0.538となり $5 \%$ 水準で有意, AFCP内FIFA RankingとAFCP Rankingに関してはスピアマ ンの順位相関係数は 0.750 となり $10 \%$ 水準で有 意, となった。

単回帰分析の結果, ACL内FIFA Ranking とACL Rankingに関しての決定係数は0.111, AFCC 内FIFA Ranking と AFCC Rankingに 関しての決定係数は0.290, AFCP内FIFA RankingとAFCP Rankingに関しての決定係数 は0.563であった。
これらの結果から, AFCCとAFCPに関して は代表成績とクラブ成績の間に相関が存在する 一方，ACLに関しては相関が存在しない事が わかった。

表 5 に当該加盟協会におけるACL内FIFA Ranking, ACL Ranking, 及び残差を示す。決 定係数が最も小さいACL内FIFA Rankingと ACL Rankingに関して更に詳細な傾向を分析 すると, 残差が正の值であり且つ絶対值が大き いカタール, サウジアラビア, 中国といった協 会及び残差が負の值であり且つ絶対值が大きい イラン，日本，オーストラリアといった協会が 決定係数の小ささに寄与している事が散見され た。

\section{4. 考察}

ACL内FIFA Ranking とACL Rankingに関し ては，相関分析及び単回帰分析の結果，両者の 間に相関が見受けられず, Leedsら ${ }^{5)}$ の研究と 同様の結論を得た。これはACLに参加する協 会においては, クラブ強化は必ずしも代表強化

表 4 順位相関係数及び決定係数

\begin{tabular}{|c|c|c|}
\hline & 相関分析 & 単回帰分析 \\
\hline & スピアマンの順位相関係数 & 決定係数 \\
\hline ACL内FIFA Ranking及びACL Ranking & 0.333 & 0.111 \\
\hline AFCC内FIFA Ranking及びAFCC Ranking & $0.538^{* *}$ & 0.290 \\
\hline AFCP内FIFA Ranking及びAFCP Ranking & $0.750^{*}$ & 0.563 \\
\hline
\end{tabular}

表 5 当該加盟協会におけるACL内FIFA Ranking, ACL Ranking、及び残差

\begin{tabular}{|l|c|c|r|}
\hline \multicolumn{1}{|c|}{ 加盟協会 } & ACL内FIFA Ranking & ACL Ranking & 残差 \\
\hline Korea Republic & 3 & 1 & -0.7 \\
\hline Saudi Arabia & 7 & 2 & 3.0 \\
\hline Iran & 1 & 3 & -3.3 \\
\hline Japan & 2 & 4 & -2.7 \\
\hline Qatar & 9 & 5 & 4.0 \\
\hline Uzbekistan & 5 & 6 & -0.3 \\
\hline China PR & 8 & 7 & 2.3 \\
\hline Australia & 4 & 8 & -2.0 \\
\hline United Arab Emirates & 6 & 9 & -0.3 \\
\hline
\end{tabular}

回帰係数 : 0.333 切片 : 3.333 
の為の有効な施策ではない事を示している. その一方で, AFCC内FIFA RankingとAFCC Ranking, 及びAFCP内FIFA RankingとAFCP Rankingに関しては，代表成績とクラブ成績の 相関が見受けられた。即ち, AFCC, AFCPに 参加するアジアの中堅・弱小協会においては, クラブ強化は代表強化の為の有効な施策の 1 つ である事を示している。

$\mathrm{ACL} \mathrm{AFCC} \cdot \mathrm{AFCP}$ 間で結果が異なった 理由として以下の 2 点が考えられる．1点目 は「ACL参加協会においては, AFCC参加協会 やAFCP参加協会に比べ，一部のクラブが非常 に優秀な外国人選手を有している為, 代表成績 に比べACL成績が良くなる」という点であり， 2 点目は「ACL参加協会においては, AFCC 参加協会やAFCP参加協会に比べ, 一部の代表 チームがアジアよりレベルの高いヨーロッパの リーグでプレーしている選手を有している為, ACL成績に比べ代表成績が良くなる」という 点である。

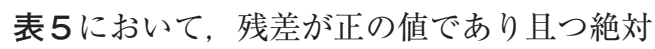
值が大きいカタール, サウジアラビア, 中国と いった協会は上述の 1 点目に該当すると考えら れる．例えば，2011年に優勝したカタールのア ル・サッドはフランスリーグで101ゴールの実 績を持つセネガル人選手, 2012年に準優勝した サウジアラビアのアル・アハリは得点ランキン グ 3 位となったブラジル人選手, 2013年に優勝 した中国の広州恒大は得点ランキング 1 位のブ ラジル人選手及び 2 位アルゼンチン人選手をそ れぞれ有していた。

また, 表5において残差が負の值であり且つ 絶対值が大きいイラン, 日本, オーストラリア は上述の 2 点目に該当すると考えられる. 例え ば, 2011年アジアカップの登録メンバーを見る と, イランのネコナム, 日本の香川, オースト ラリアのケーヒル，といったヨーロッパのクラ ブで主力として活躍する選手を有していた.

冒頭で述べたように日本のクラブは近年 ACLで苦戦を強いられているが, 上記の結果 から, 代表の成績への影響は必ずしも大きい訳
ではないと考えられ，原専務理事のコメントは 必ずしも妥当ではない可能性がある.

その一方で, ACLにおける日本のクラブの 苦戦により，Jリーグのアジアに拈けるイメー ジダウンの可能性も考えられる. 折しも Jリー グはアジア戦略と銘打ってアジアへの売り込み を試みているが，JリーグクラブのACLにお ける成績と J リーグの商業的価值の関連に関し ては今後の研究課題の 1 つであると考えられ る。

\section{5. 結論}

本研究では, AFCに加盟する32協会におけ る代表成績とクラブ成績との関係について統計 的に明らかにし，アジアにおいてクラブ強化が 代表強化に繋がる有効な施策の 1 つと成り得る か考察を行う事を目的とした。

代表成績にはFIFA/Coca-Cola World Ranking を基に, ACL内FIFA Ranking, AFCC内FIFA Ranking, AFCP内FIFA Rankingを,クラブ成 績にはACL，AFCC，AFCPにおける成績を数 值化したものを用い，代表成績とクラブ成績と の関係について単回帰分析及び相関分析を行っ た。

分析結果から, ACL参加協会においては 代表成績とクラブ成績の相関は見受けられ ず，ACLに参加するアジアの強豪協会におい ては, クラブ強化は必ずしも代表強化の為の 有効な施策ではない事が示された。その一方 で, AFCC・AFCP参加協会においては代表成 績とクラブ成績の相関が見受けられ，AFCC， $\mathrm{AFCP}$ に参加するアジアの中堅・弱小協会にお いては, クラブ強化は代表強化の為の有効な施 策の 1 つである事が示された。

\section{参 考 文 献}

1) http : //www.the-afc.com/en/afc-presidentsub/afc-pres-news/28939-afc-presidentremains-positive-on-asia-s-potential.html.

2) http : //sportsnavi.yahoo.co.jp/sports/soccer/ japan/2014/columndtl/201409270002-spnavi. 
3) http : //www.jfa.or.jp/jfa/terminology/.

4) Hoffmann, Robert., et al. ; The Socio-economic determinations of intentional soccer performance, Journal of Applied Economics, Vol.V, No.2, pp.253-272, 2002.

5 ) Leeds, Michael A. and Leeds, Eva Marikova. ; International soccer success and national institutions, Journal of Sports Economics, 10.4, pp.369-390, 2009.

6 ) Baur, Dirk. and Sibylle Lehmann.; Does the mobility of football players influence the success of the national team?, IIIS Discussion Paper No.217, Available at SSRN : http :// ssrn.com/abstract=980936 or http : //dx.doi. org/10.2139/ssrn.980936, 2007.

7 ) FIFA/Coca-Cola World Ranking, http : // www.fifa.com/worldfootball/ranking/ lastranking/gender=m/fullranking.html.

8 ) http : //www.uefa.com/MultimediaFiles/ Download/Regulations/competitions/Regulations/ 01/94/62/34/1946234_DOWNLOAD.pdf.

9 ) http : //int.soccerway.com/.

10）平田竹男, 他; 浦和レッドダイヤモンズの自 律的経営と成長要因, スポーツ産業学研究 Vol.18, No.1, pp.59-77, 2008. 
